
університету. - Серія "Регіональна економіка". - Випуск 16 (63). - Редкол.: відп. ред. д.е.н., професор Л.Л. Ковальська - Луцьк : ІВВ Луцького НТУ, 2019. -173 с.

УДК 338.49:330.341.1

Рудь Н.Т., д.е.н., професор

Луцький національний технічний університет

\title{
ІННОВАЦІЙНИЙ РОЗВИТОК РЕГІОНУ: ПОПИТ НА ІННОВАЦІЙНУ ІНФРАСТРУКТУРУ
}

У статті досліджено місце інноваційної інфраструктури в регіональній інноваційній системі. Вказано на законодавчу базу ㄲi формування. Підтверджена органами статистики низька доля витрат на фінансування науки. Вказано частку витрат на наукові дослідження в країнах $Є С-28$. Показано, що кадровий потенціал перетікає в країни Свропи. Наведено приклади залучення студентів до інновацій в Ірландії. Відмічено, що інноваційний бізнес не формує попит на інноваційну інфраструктуру. Відсутність підтримки інноваційною інфраструктурою не сприяе інноваційному розвитку підприємств. Запропоновано формувати маркетингову стратегію розвитку інноваційної інфраструктури. Уточнено коло питань для вирішення.

Ключові слова: регіон, інноваційна інфраструктура, попит, маркетинг, стратегія, політика.

Rud N.

\section{INNOVATIVE DEVELOPMENT OF THE REGION: DEMAND FOR INNOVATIVE INFRASTRUCTURE}

The article investigates the place of innovative infrastructure in the regional innovation system. The legislative basis for its formation is indicated. A low percentage of the cost of funding science, which generates ideas and develops and patents them, is endorsed by statistics. The share of expenditures on research in the EU - 28 countries is indicated.

It is shown that human resources flow to European countries. Examples are given of engaging students in innovation in Ireland, where the Business Academy Business Incubator operates, which supports people who want to start a business.

It is noted that innovative business does not generate demand for innovative infrastructure: low innovation activity, thus a small share of innovative products.

Lack of support for innovative infrastructure does not contribute to the innovative development of enterprises.

It is proposed to formulate a marketing strategy for the development of innovative infrastructure. The range of issues to be resolved has been clarified.

Key words: region, innovative infrastructure, demand, marketing, strategy, policy. 
Економічні науки: збірник наукових праџь Луцького національного технічного університету. - Серія "Регіональна економіка". - Випуск 16 (63). - Редкол.: відп. ред. д.е.н., професор Л.Л. Ковальська - Луцьк : ІВВ Луцького НТУ, 2019. -173 с.

Рудь Н.Т.

\section{ИННОВАЦИОННОЕ РАЗВИТИЕ РЕГИОНА: СПРОС НА ИННОВАЦИОННУЮ ИНФРАСТРУКТУРУ}

В статье исследовано место инновационной инфраструктуры в региональной инновационной системе. Указано на законодательную базу ее формирования. Подтверждена органами статистики низкая доля расходов на финансирование науки. Указано долю расходов на научные исследования в странах ЕC - 28. Показано, что кадровый потенциал перетекает в страны Европы. Приведены примеры привлечения студентов к инновациям в Ирландии. Отмечено, что инновационный бизнес не формирует спрос на инновационную инфраструктуру. Отсутствие поддержки инновационной инфраструктурой не способствует инновационному развитию предприятий. Предложено формировать маркетинговую стратегию развития инновационной инфраструктуры. Уточнен круг вопросов для решения.

Ключевые слова: регион, инновационная инфраструктура, спрос, маркетинг, стратегия, политика.

Постанова проблеми у загальному вигляді та її зв'язок 3 важливими науковими та практичними завданнями. При формуванні моделі регіональної інноваційної системи, одну із ключових ролей відіграє інноваційна інфраструктура, яка забезпечує горизонтальні і вертикальні зв' язки між суб' єктами інноваційної діяльності. Зокрема, основними елементами інфраструктури $\epsilon$ : інноваційні і технологічні центри, бізнесінкубатори, технопарки, наукові парки i технополіси, інноваційні та венчурні фонди, центри трансферу технологій, інформаційні платформи та інші. Досвід розвинених країн свідчить, що такі інноваційні структури створюють сприятливі умови для ефективної діяльності та розвитку малих інноваційних підприємств, які реалізують оригінальні науковотехнічні ідеї.

Аналіз останніх досліджень і публікацій. Проблема забезпечення підтримки інноваційних підприємств шляхом побудови (створення) інноваційної інфраструктури стала об'єктом уваги законодавців і практиків з кінця 1990-х років, коли Україна задекларувала необхідність переходу економіки на інноваційний шлях розвитку. Теоретичні та прикладні аспекти 
Економічні науки: збірник наукових праџь Луцького національного технічного університету. - Серія "Регіональна економіка". - Випуск 16 (63). - Редкол.: відп. ред. д.е.н., професор Л.Л. Ковальська - Луцьк : ІВВ Луиького НТУ, 2019. - 173 с.

формування і функціонування інноваційної інфраструктури та іiі складових розглядаються у роботах як вітчизняних, так i зарубіжних вчених, зокрема В. Орлової, Dennis J. Heindl, Л. Малюти, А. Князевич, I Кадирус, О. Тимченко, В. Камінського, О. Колінько, Ю. Марчук, Т. Небоги, О. Христиненко, Н. Махеди, В. Кафлевського, І. Одотюк, В. Бабаєва, В. Гейця та ін.

Цілі статті - дослідження впливу інноваційної інфраструктури на інноваційний розвиток., формування попиту на неї.

Виклад основного матеріалу з повним обгрунтуванням отриманих наукових результатів. Виходячи із тенденцій розвитку сучасного світу, можна зробити висновок, що локомотивом росту економіки успішних країн $є$ нові знання та оригінальні ідеї, які разом з фінансовими та матеріальними ресурсами забезпечують створення конкурентоспроможних товарів. Інноваційна політика розвинених країн, таких, як: Великобританія, Німеччина, Італія, Канада, Японія - поступово переорієнтовуються 3 формування виключно інноваційної економіки до побудови нового інноваційного суспільства [1]. В такому суспільстві більшість працюючих зайнята у сфері інновацій, а провідна роль належить університетам.

Освоєння інновацій завжди пов'язане 3 підвищеним рівнем ризику. Більшість виробників, підприємців та інвесторів досить скептично відносяться до наукових ідей чи інноваційних пропозицій, які ще не випробувані на практиці. Тому виникає необхідність доведення наукових ідей, пропозицій, новітніх технічних розробок до виду інноваційного проекту, переконливого у своїй рентабельності та зрозумілого для інвесторів і підприємців [2, с. 134]. Таку роботу виконує інноваційна інфраструктура.

Розглянемо інноваційну інфраструктуру в контексті ланцюга «держава - освіта - наука - підприємництво» (рис. 1). 
Економічні науки: збірник наукових праџь Луцького національного технічного університету. - Серія "Регіональна економіка". - Випуск 16 (63). - Редкол.: відп. ред. д.е.н., професор Л.Л. Ковальська - Луцьк : ІВВ Луцького НТУ, 2019. -173 с.

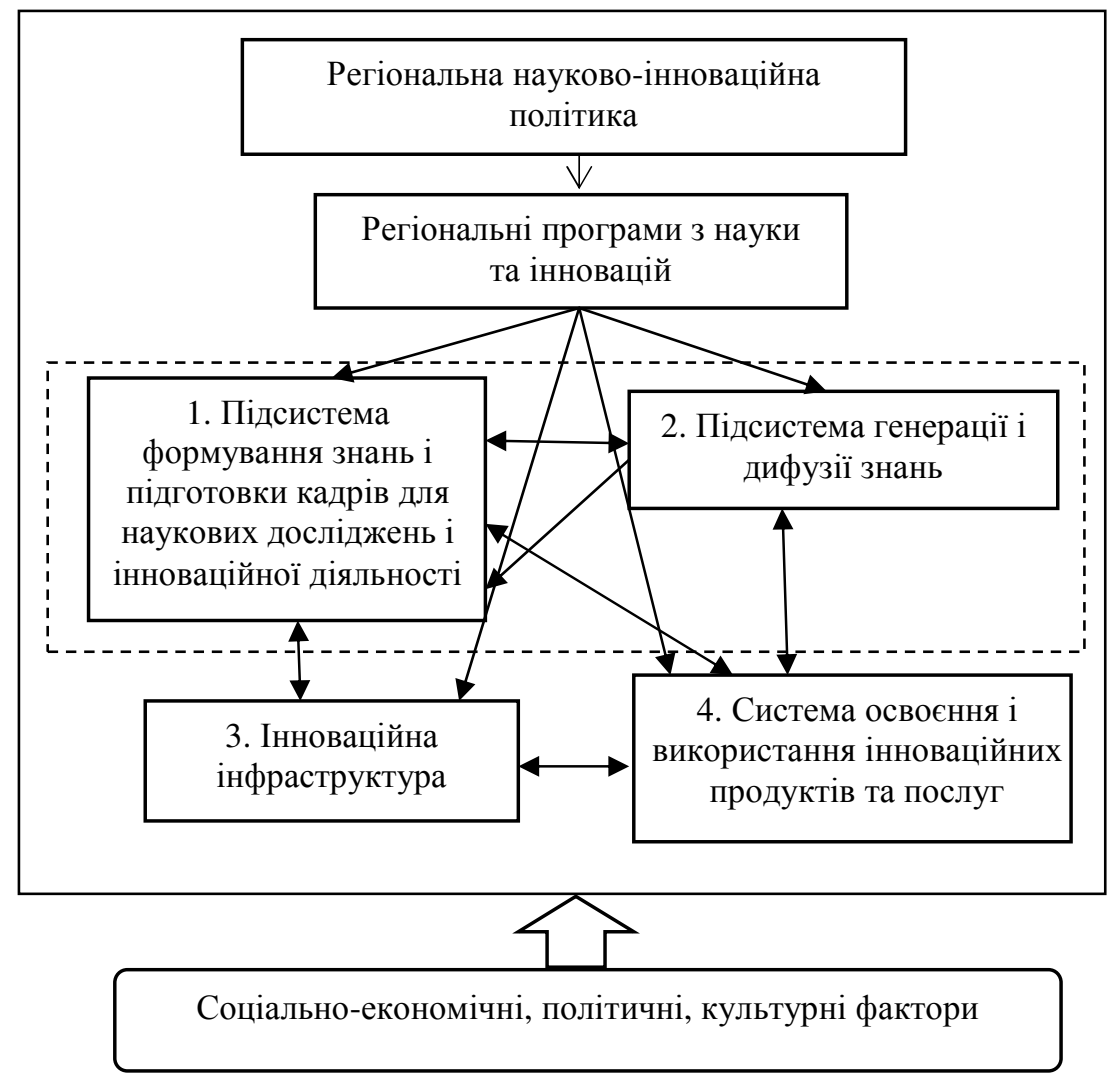

Рис. 1. Місце інноваційної інфраструктури в РІС (складено авторами)

В Україні інноваційна інфраструктура є нерозвиненою і не охоплює усі ланки інноваційного процесу. Важливу роль у формуванні як самої інноваційної інфраструктури, так і попиту на неї відіграє держава, яка формує політико-правове середовище науково-інноваційної діяльності в країні.

На створення інноваційної інфраструктури 3 метою сприяння інноваційному розвитку економіки країни була спрямована «Концепція розвитку національної інноваційної 
Економічні науки: збірник наукових праиь Луиького національного технічного університету. - Серія "Регіональна економіка". - Випуск 16 (63). - Редкол.: відп. ред. д.е.н., професор Л.Л. Ковальська - Луцьк : ІВВ Луцького НТУ, 2019. -173 с.

системи» [3] та Державна цільова економічна програма «Створення в Україні інноваційної інфраструктури» на 20092013 роки [4, с. 157].

У листопаді 2015 року прийнятий проект Державної цільової економічної програми розвитку інноваційної інфраструктури на 2017-2021 роки, що має на меті створення умов для розвитку інноваційної інфраструктури, яка сприятиме формуванню інноваційної моделі розвитку національної економіки [5].

Попередня концепція (2006 рік), проект (2007 рік) i затверджена програма (2008 рік) не принесла результату, оскільки не була профінансована. Проблеми, які стримували розвиток інноваційної інфраструктури та практично сприяли зменшенню попиту на неї, залишилися без змін. Так, зовсім відсутнє спрощення процедури створення технологічних парків та запровадження сприятливих економічних умов їх діяльності, низька інноваційна активність підприємств,

Недостатній рівень фінансування інноваційної діяльності (як підприємствами, так і державою) об'єктивно унеможливлює отримання від суб'єктів господарювання суттєвої економічної віддачі. За попередніми розрахунками органів статистики, у 2017 році в Україні питома вага загального обсягу витрат на наукові дослідження у ВВП становила $0,45 \%$, у тому числі за рахунок коштів державного бюджету - 0,16\% [6]. Саме наукова сфера генерує ідеї, розробки, які патентуються, що дає можливість бізнесу використовувати їх у виробництві.

За даними Євростату частка обсягу витрат на наукові дослідження та розробки у ВВП країн СС-28 у середньому становила 2,03\%, у Китаї - 2,08\%, США - 2,77\%, Японії $3,47 \%$, Південній Кореї - 4,15\%. Слід зазначити, що динаміка витрат на наукові дослідження у $\mathrm{CC}$ та інших зазначених країнах протягом останнього десятиліття була позитивною.

Наприклад, у Південній Кореї за період 2004-2014 років частка витрат зросла майже удвічі - 3 2,35\% до 4,15\% у ВВП. Натомість в Україні спостерігаються протилежні тенденції: частка витрат на наукові дослідження скоротилася з 1,06\% ВВП 
Економічні науки: збірник наукових праиь Луиького національного технічного університету. - Серія "Регіональна економіка". - Випуск 16 (63). - Редкол.: відп. ред. д.е.н., професор Л.Л. Ковальська - Луцьк : ІВВ Луцького НТУ, 2019. -173 с.

у 2003 році до 0,62 \% у 2015 році. Загальновідомо, що для самовідтворення наукової сфери іiі фінансування має проводитися на рівні не нижче 0,9 відсотка ВВП, чого в Україні не спостерігається [7].

Велика роль у розвитку інноваційної інфраструктури належить іiі кадровому потенціалу. Тому зважена державна політика стосовно збереження і розвитку кадрового потенціалу [8] для інноваційної економіки $є$ запорукою успіху держави на світових ринках, бо інноваційна інфраструктура забезпечує темпи (швидкість) розвитку економіки країни і зростання добробуту населення.

В Україні відбувається колосальний відплив інтелекту, причому система «вимивання» мізків цілеспрямована, ще зі шкільної лави. Кількість молодих українських вчених, що прагнуть виїхати за кордон та реалізувати себе в розвинених країнах, просто вражає: в самій лише Німеччині сьогодні навчаються і працюють 25 тисяч осіб з України, які отримують грантову підтримку від держави. Німеччина, поряд 3 деякими іншими європейськими країнами, активно зацікавлена в припливі інтелектуального ресурсу з-за кордону, і Україна (якщо не порівнювати іiі з РФ) забезпечує Свропі більший приплив освіченої молоді, ніж всі інші країни колишньої співдружності [9]. За роки незалежності в Україні в рази скоротилася кількість вчених та дослідників: 3 449,8 тисяч осіб у 1991році до 88,128 тисяч осіб у 2018 році.

Значний досвід в розвитку інноваційної інфраструктури мають європейські країни, зокрема Ірландія. В Ірландії всі наукові дослідження проводяться в університетах: 80\% фінансових ресурсів, що спрямовані на проведення досліджень, виділяються державою, яка чекає від цього створення нових робочих місць, надходження інвестицій в країну. В університетах активно до інновацій залучаються студенти.

В Ірландії успішно функціонує бізнес-інкубатор «Академія підприємництва», який разом з університетом DCU займається реалізацією потенціалу незайнятих людей, студентів, науковців і підприємців, розробкою і втіленням їх ідей та 
Економічні науки: збірник наукових праџь Луцького національного технічного університету. - Серія "Регіональна економіка". - Випуск 16 (63). - Редкол.: відп. ред. д.е.н., професор Л.Л. Ковальська - Луцьк : ІВВ Луиького НТУ, 2019. - 173 с.

проведенням тренінгів, спрямованих на підтримку бізнесінновацій шляхом передачі навичок підприємницької діяльності дослідникам, науковим співробітникам, студентам, які хочуть відкрити свою справу. Наставництво в проектах здійснюється у формі консалтингової підтримки, наданні грантів, розробці і впровадження проектів. Президент Ірландії опікується і приймає участь у новій стратегії університету, як організації, що готує підприємців. Завдання бізнес-інкубатора - створення нових робочих місць і стимулювання освоєння інновацій в ірландських компаніях. Програмою передбачено річний курс заняття студентів і незайнятих людей тричі на тиждень 3 метою реалізації їх проекту, отримання фінансування чи працевлаштування [10].

Особливим елементом інноваційної системи $\epsilon$ інноваційний бізнес. Бізнес може бути драйвером інноваційного розвитку [11]. Динаміку інноваційної активності вітчизняних підприємства наведено в таблиці 1.

За наведеними даними у 2009-2012 рр. спостерігається зростання питомої ваги підприємств, що займалися інноваціями, а в 2013-2014 pp. - зниження частки таких підприємств. У 2015 р. інноваційна активність вітчизняних підприємств досягла рівня 2012 р.: 17,3\% підприємств займалися інноваціями. Питома вага підприємств, що освоювали інновації в 2015 р. складає 15,2\%; порівняно 32014 р. підвищення на 25,6\%. Показники ж питомої ваги реалізованої інноваційної продукції, на жаль, мають тенденцію до поступового зменшення [12, с. 133]. У 2018 році показники майже не змінились: Займалися інноваціями - 16,4\%; освоювали - 15,6\%; доля інноваційної продукції склала - 0,8\%. Дуже низькі показники порівняно з розвиненими країнами.

Нерозвиненість інноваційної інфраструктури та низька іiі якість зумовлює високі трансакційні витрати, пов'язані 3 пошуком інформації про інноваційні розробки та партнерів у сфері комерціалізації технологій і винаходів, захистом прав інтелектуальної власності [13]. 
Економічні науки: збірник наукових праџь Луцьького національного технічного університету. - Серія "Регіональна економіка". - Випуск 16 (63). - Редкол.: відп. ред. д.е.н., професор Л.Л. Ковальська - Луцьк : ІВВ Луцького НТУ, 2019. -173 с.

Таблиця 1

Інноваційна діяльність вітчизняних промислових підприємств

\begin{tabular}{|c|c|c|c|c|c|c|c|c|c|}
\hline Показники & ஓे & 음 & $\overline{\vec{ন}}$ & $\stackrel{\sim}{\stackrel{\sim}{2}}$ & $\stackrel{m}{\stackrel{n}{0}}$ & $\stackrel{\Delta}{\stackrel{\sim}{d}}$ & $\frac{n}{2}$ & $\stackrel{0}{\stackrel{0}{2}}$ & 홍 \\
\hline \begin{tabular}{l|} 
Частка \\
підприємств, \\
що займалися \\
інноваціями, \%
\end{tabular} & 12,8 & 13,8 & 16,2 & 17,4 & 16,8 & 16,1 & 17,3 & 18,9 & 16,2 \\
\hline \begin{tabular}{l|} 
Частка \\
підприємств, \\
що освоювали \\
інновації, \% \\
\end{tabular} & 10,7 & 11,5 & 12,8 & 13,6 & 13,6 & 12,1 & 15,2 & 14,3 & 14,3 \\
\hline $\begin{array}{l}\text { Частка } \\
\text { реалізованої } \\
\text { інноваційної } \\
\text { продукції в } \\
\text { обсязі } \\
\text { промислової, } \\
\text { \% }\end{array}$ & 4,8 & 3,8 & 3,8 & 3,3 & 3,3 & 2,5 & 1,4 & 1,4 & 0,7 \\
\hline
\end{tabular}

Залучити бізнес і суспільство до підтримки інновацій можна популяризуючи «історії успіху». Навколо успішних проектів 3 часом можуть виникнути цілі кластери, які будуть працювати в тих секторах економіки, де Україна має конкурентні переваги. Інновації мають стати національною ідеєю. Бізнес готовий інвестувати, але не знає, що пропонує наука. Тому необхідно підвищувати рівень знань у вчених про підприємництво, а у підприємців - про науку, іiі сутність, можливості і історичну роль [14].

Інвестори, які вкладають кошти в інновації за кордоном, мають податкові та інші пільги, а держава послідовно працює над створенням інноваційної інфраструктури.

Досвід розвинених країн світу підтверджує, що в умовах глобальної конкуренції на світовому ринку виграє той, хто має 
Економічні науки: збірник наукових праџь Луцького національного технічного університету. - Серія "Регіональна економіка". - Випуск 16 (63). - Редкол.: відп. ред. д.е.н., професор Л.Л. Ковальська - Луцьк : ІВВ Луиького НТУ, 2019. - 173 с.

розвинену інфраструктуру створення і реалізації інновацій, хто володіє ефективним механізмом інноваційної діяльності $[15$, с. 16]. Попит на інноваційну інфраструктуру буде наявним у тому випадку, коли всі елементи ланцюга «маркетинг - наука технологія - виробництво - ринок» будуть злагоджено функціонувати.

Формування маркетингової стратегії розвитку інноваційної інфраструктури повинно передбачати вирішення наступних питань:

1. Реалізація державної політики у сфері розвитку інноваційної інфраструктури:

- провести гармонізацію інвестиційного законодавства України $з$ міжнародними угодами і конвенціями у договірноправовій сфері міжнародної науково-технічної кооперації зі стратегічно важливими партнерами;

- встановити податкові пільги, фінансову допомогу підприємствам, організаціям та об'єктам інфраструктури, компенсацію процентних ставок за кредитами, встановлення митних тарифів та квот [16, с. 222];

- удосконалити нормативно-правові акти i розпорядчі документи, що стосуються елементів інноваційної інфраструктури відповідно до існуючих нормативно-правових актів розвинутих країн світу, але 3 урахування специфіки інноваційного розвитку в Україні;

- розробити програми розвитку інноваційної інфраструктури у співпраці 3 органами місцевого самоврядування, надавати допомогу при створенні та реєстрації об'єктів інноваційної інфраструктури;

- надати цільові субсидії технологічним (науковим) паркам та бізнес-інкубаторам для придбання дослідницького та комп'ютерного обладнання, програмного забезпечення тощо;

- забезпечити відкритий доступ (платний чи безкоштовний) до бази наукових розробок зацікавленим юридичним чи фізичним особам $[17$, с. 8$]$;

- забезпечити розвиток виробничо-технологічної інноваційної інфраструктури шляхом сприяння створенню 
Економічні науки: збірник наукових праџь Луцького національного технічного університету. - Серія "Регіональна економіка". - Випуск 16 (63). - Редкол.: відп. ред. д.е.н., професор Л.Л. Ковальська - Луцьк : ІВВ Луцьккого НТУ, 2019. -173 с.

інноваційних структур, які будуть орієнтовані на підтримку бізнесу;

- надати економічні стимули для розвитку наукових парків на базі вищих закладів освіти, а також інноваційних структур різних типів.

2. Збільшення витрат на науку. Це створить попит на інноваційну інфраструктуру системи генерації знань. Нині витрати на науку становлять $0,62 \%$ від ВВП, а в Законі України «Про наукову і науково-технічну діяльність» передбачено 1,7\% від ВВП.

3. Створення інтелектуальних ініціатив через розвиток адаптивної освіти і системи перепідготовки кадрів - дозволить залучити до інноваційної діяльності максимальну кількість людей.

4. Зменшення відпливу інтелекту 3 країни, який $\epsilon$ необхідним для функціонування інноваційної економіки та інноваційної інфраструктури, за рахунок надання фінансових, житлових преференцій та сприяння у впровадженні ідей i розробок.

5. Сприяння формуванню інноваційної культури для створення в суспільстві атмосфери, при якій нова ідея сприймається як цінність, що приймається цим суспільством і підтримується ним. Для цього потрібно за допомогою освіти та науки розробити в суспільстві здатність виходити за межі знань і досвіду, в економіці та підприємницькій діяльності стимулювати появу інновацій та інноваторів шляхом залучення їх до участі у прибутку від інновацій; реалізувати свободу творчості особистості від політичних, релігійних, бюрократичних та інших обмежень, внаслідок чого має зменшитись опір суспільства до нововведень, підвищити рівень інноваційної культури особистості за допомогою введення ідеології інноваційного розвитку в освіту [18, с. 32]. Потрібно популяризувати інтерес до науки ще 3 дитинства шляхом внесення інновацій в сам процес навчання.

Висновок. Ефективно функціонуюча інноваційна інфраструктура $\epsilon$ ключовою ланкою в переведенні знань у 
Економічні науки: збірник наукових праџь Луцького національного технічного університету. - Серія "Регіональна економіка". - Випуск 16 (63). - Редкол.: відп. ред. д.е.н., професор Л.Л. Ковальська - Луцьк : ІВВ Луиького НТУ, 2019. - 173 с.

матеріальне багатство країни. Як складова частина національної інноваційної системи інноваційна інфраструктура сприяє підвищенню конкурентоспроможності вітчизняного виробника на світовому ринку. Без сумніву вона дозволяє підприємствам одержати необхідну інноваційну розробку, науково-освітньому сектору - реалізувати наукові ідеї, а державі - збільшити національне багатство. Відсутність розвиненої інноваційної інфраструктури є однією із головних проблем прогресивного розвитку України. Щоб сформувати попит на інноваційну інфраструктуру в першу чергу необхідно розвивати інноваційне середовище усієї країни, а також створити такі умови, які стимулюватимуть підприємства використовувати у своїх виробничих процесах інноваційні технології.

1. Світові лідери у сфері інновацій. 2015.URL: http://iac.org.ua/svitovilideri-u-sferi-innovatsiy/.

2. Князевич А.О. Ринок інновацій у складі інноваційної інфраструктури країни. Маркетинг і менеджмент інноваиій. 2015.№3. 129-139.

3. Про схвалення Концепції розвитку національної інноваційної системи» від 17.06.2009 p. №680-p. Інвестиції та інноваційний розвиток (Науково-практичний бюлетень). 2009. №4(7). С. 40-44.

4. Постанова КМУ №447 від 14.05.2008p. «Про затвердження Державної цільової економічної програми «Створення в Україні інноваційної інфраструктури на 2009 - 2013 роки».

5. Проект Концепції Державної цільової економічної програми розвитку інноваційної інфраструктури на 2017-2021 роки. URL: http://cg.gov.ua/web_docs/1/2015/10/docs/\%D0\%9F\%D1\%80\%D0\%BE\%D0\%B5\%D0 $\% \mathrm{BA} \% \mathrm{D} 1 \% 82 \% 20 \% \mathrm{D} 0 \%$

6. Наукова та інноваційна діяльність в Україні. Статистичні збірники. URL: http://www.ukrstat.gov.ua/

7. Фінансування наукових досліджень в Україні та світі. Економічний дискусійний клуб. 2016. URL: http://edclub.com.ua/analityka/finansuvannyanaukovyh-doslidzhen-v-ukrayini-ta-sviti.

7. Постанова Верховної Ради України Про Рекомендації парламентських слухань на тему: «Про стан та законодавче забезпечення розвитку науки та науково-технічної сфери держави» [Електронний ресурс] // Відомості Верховної Ради. - 2015. - Режим доступу до ресурсу: http://zakon2.rada.gov.ua/laws/show/182-19.

8. Зеркіна О.О. Формування системи кадрового забезпечення інноваційного розвитку регіональної економіки: автореф. дис. на здобуття 
Економічні науки: збірник наукових праџь Луцького національного технічного університету. - Серія "Регіональна економіка". - Випуск 16 (63). - Редкол.: відп. ред. д.е.н., професор Л.Л. Ковальська - Луцьк : ІВВ Луцького НТУ, 2019. -173 с.

наук. ступеня канд. ек. наук: спец. 08.00.05 «Розвиток продуктивних сил i регіональна економіка» Одеса, 2016. 21 с.

9. Відплив наукового потенціалу з України набув масштабів стихійного лиха. 2016.

URL: http://ua.censor.net.ua/news/382783/vidplyv_naukovogo_potentsialu_z_ukrayiny_n abuv_masshtabiv_styhiyinogo_lyha_dyrektor_derjfondu_fundamentalnyh.

10. Інноваційна інфраструктура Республіки Ірландія: Інноваційне підприємництво. URL: http://www.researchclub.com.ua/jornal/151.

11. .Бізнес готовий інвестувати в інновації, але не знає, що пропонує наука.

URL: http://espreso.tv/news/2016/11/28/biznes_gotovyy_investuvaty_v_innovaciyi_ale_n e znaye scho proponuye nauka yankovskyy.

12. Орлова В.М., Кузьменко О.В., Сергеєва О.Р. Щодо інноваційної активності підприємства на різних етапах розвитку. Свропейський вектор економічного розвитку. 2016. С. 112-120.

13. Дєгтяр А.О., Соболь Р.Г., Календжян Я.В.. Теоретичні засади державного регулювання інноваційної інфраструктури: метод. ред.. Київ: НАДУ, 2012. 40 с.

14. Герасимчук 3.В., Рудь Н.Т. Інфраструктурне забезпечення інноваційних процесів: монографія. Луцьк: Вежа-Друк, 2013. 260с.

15. Dennis J. Heindl. Innovation Infrastructure [Електронний ресурс] / Dennis J. Heindl // White Paper. - 2008. - Режим доступу до ресурсу: http://innovationmanagement.se/wpontent/uploads/pdf/Innovation_Infrastructure_H eindl.pdf

16. Бабаєв В.Ю., Дрожжин Д.Ю. Механізм державного регулювання розвитку інноваційної інфраструктури в Україні. Теорія та практика державного управління. 2012. С. 214-223.

17. Небога Т.В. Формування інноваційної інфраструктури як пріоритетний напрямок економічної політики держави. URL: http://www.rusnauka.com/25_NPM_2009/Economics/51403.doc.htm.

18. Соболь Т.В. Інноваційна культура як основа розвитку сучасного суспільства. Вісник КНУ ім. Тараса Шевченка. 2014. С. 29-32. 